\title{
Small-scale variation of vegetation in a mixed forest understorey is partly controlled by the effect of overstory composition on litter accumulation
}

\author{
J. Rodríguez-Calcerrada $\cdot$ N. Nanos $\cdot$ \\ M. C. del Rey • U. López de Heredia • \\ R. Escribano • L. Gil
}

\begin{abstract}
We investigated how richness and composition of vascular plant species in the understory of a mixed hardwood forest stand varied with respect to the abundance and composition of the overstory. The stand is in central Spain and represents the southernmost range of distribution of several tree and herbaceous species in Europe. Understory species were identified in 46 quadrats $\left(0.25 \mathrm{~m}^{2}\right)$ where variables litter depth and light availability were measured. In addition, we estimated tree density, basal area, and percent basal area by tree species within 6-mradius areas around each plot. Species richness and composition were studied using path analysis and scaledependent geostatistical methods, respectively. We found that the relative abundance of certain trees species in the overstory was more important than total overstory abundance in explaining understory species richness. Richness decreased as soil litter depth increased, and soil litter increased as the relative proportion of Fagus sylvatica in the overstory increased, which accounted for a negative, indirect effect of Fagus sylvatica on richness. Regarding understory species composition, we found that some species distributed preferentially below certain tree species. For example, Melica unifora was most frequent below Fagus sylvatica and Quercus petraea while the increasing proportion of $Q$. pyrenaica in the overstory favored the presence of Cruciata glabra, Arenaria montana, Prunus avium, Conopodium bourgaei, Holcus mollis, Stellaria
\end{abstract}

J. Rodríguez-Calcerrada - M. C. del Rey

Centre of Functional and Evolutionary Ecology, CNRS,

1919 Route de Mende, Montpellier, France

N. Nanos · U. L. de Heredia - R. Escribano - L. Gil ( $\square$ )

School of Forest Engineering, Technical University of Madrid (UPM), Ciudad Universitaria s/n, 28040 Madrid, Spain

e-mail: luis.gil@upm.es media and Galium aparine in the understory. Overall, these results emphasize the importance of individual tree species in controlling the assemblage and richness of understory species in mixed stands. We conclude that soil litter accumulation is one way through which overstory composition shapes the understory community.

Keywords Canopy closure - Linear model of coregionalization - Litter - Multiscale ordination . Understory richness

\section{Introduction}

Diversity of herbaceous species is generally low in the understory of closed-canopy mature forest stands. Trees exert a strong competition for resources, and litter accumulates in the soil making conditions unsuitable for a number of species (Bazzaz 1996; Howard and Lee 2003). The apparent homogeneity of a dense mature forest reveals, however, subtle differences in the assemblage and richness of understory species (Borchsenius et al. 2004; MaltezMouro et al. 2005). Shifts in understory composition arise in part from the distinct capacity of species to accommodate to the environmental patches that the overstory structure creates. The spatial pattern may be common to species that share broad ecological traits and competitive abilities along their life cycle, which enable them to spread and establish into the same microsites. For example, small openings in the canopy can create understory conditions adequate for many species, thus enhancing diversity (Schumann et al. 2003).

The environment in the forest understory is also modified by the phenological, functional and anatomical traits of the tree species integrating the overstory (Canham et al. 1994; 
Komiyama et al. 2001; Kato and Komiyama 2002). Every species exerts an influence on below- and above-ground properties that varies in spatial extent, intensity, and period of occurrence. For example, overstory composition affects soil litter accumulation (Maltez-Mouro et al. 2005), as tree functional characteristics determine the production and decomposability of their litter (Pérez-Harguindeguy et al. 2000). Litter, in turn, generally reduces species richness in temperate and Mediterranean forests (Borchsenius et al. 2004; Casado et al. 2004), and it modulates community composition through distinct species responses to its accumulation in the soil (Sydes and Grime 1981; Facelli and Pickett 1991). Thus, the variation in the relative proportion of certain trees within mixed forests sometimes alters the composition and richness of species in the understory (Beatty 1984; Crozier and Boerner 1984; Berger and Puettmann 2000; Jobidon et al. 2004; Maltez-Mouro et al. 2005; but see Thomsen et al. 2005). Seemingly, as the relative abundance of species with a high capacity to deplete resources increases in the overstory, fewer species are capable of establishing beneath it (see Barbier et al. 2008).

In this study, we assessed how variations in overstory abundance and composition within a closed mixed hardwood stand affected understory vascular plant species richness and composition. We hypothesized that variations of light and litter would respond to overstory features, and that light and litter, in turn, would have opposite effects on richness and would condition species composition in the understory. We studied the effect of overstory composition on the understory species assemblages with geostatistical scale-dependent techniques. The use of scale-dependent vegetation-ordination methods provides a useful insight into the effect of stand composition on understory species associations.

\section{Materials and methods}

\section{Study site}

The study site is located within a small (120 ha) mixed hardwood forest in the "Sistema Central" range of central Spain $\left(41^{\circ} 07^{\prime} \mathrm{N}, 3^{\circ} 30^{\prime} \mathrm{W}\right)$. The forest is nowadays structured in small pure and mixed stands of Fagus sylvatica, Quercus petraea and Quercus pyrenaica as the main canopy species (Pardo et al. 1997). It is a secondary forest that developed from the infilling of a wood pasture abandoned in the middle of the last century. There are several threatened herbs (Paris quadrifolia, Melica uniflora, Aconitum napellus) and trees ( $F$. sylvatica, $Q$. petraea) at or near their southernmost limit of distribution in Europe. The climate is sub-Mediterranean, with $958 \mathrm{~mm}$ annual rainfall, but dry and hot summers (rainfall and temperature in July are $27.9 \mathrm{~mm}$ and $18.8^{\circ} \mathrm{C}$, respectively).

Our study site, located at $1,410 \mathrm{~m}$ a.s.l., was about $1,875 \mathrm{~m}^{2}$ size $(75 \times 25 \mathrm{~m})$, fairly flat and homogeneous in microtopography, aspect and wind exposure. All trees larger than $2 \mathrm{~cm}$ diameter at breast height $(\mathrm{DBH})$ were positioned with a topographic Total Station (TOPCON $500)$ and their diameter measured with a digital calliper (Hagloff Digitech). Q. pyrenaica and $Q$. petraea dominate the site. There are few large old trees $(60 \mathrm{~cm}<\mathrm{DBH}<$ $130 \mathrm{~cm}$ ) of both species that remain from the wood pasture, but most are adults that recruited after grazing ceased in the 1960 s $(5 \mathrm{~cm}<\mathrm{DBH}<25 \mathrm{~cm})$. There are also patches of trees of Prunus avium, Ilex aquifolium and F. sylvatica, among other species (Fig. 1). All trees are winter-deciduous except $I$. aquifolium. The ranking of species shade tolerance is $F$. sylvatica $\geq I$. aquifolium $>Q$. petraea $\geq Q$. pyrenaica $>P$. avium. Shrubs were mostly absent in the understory.

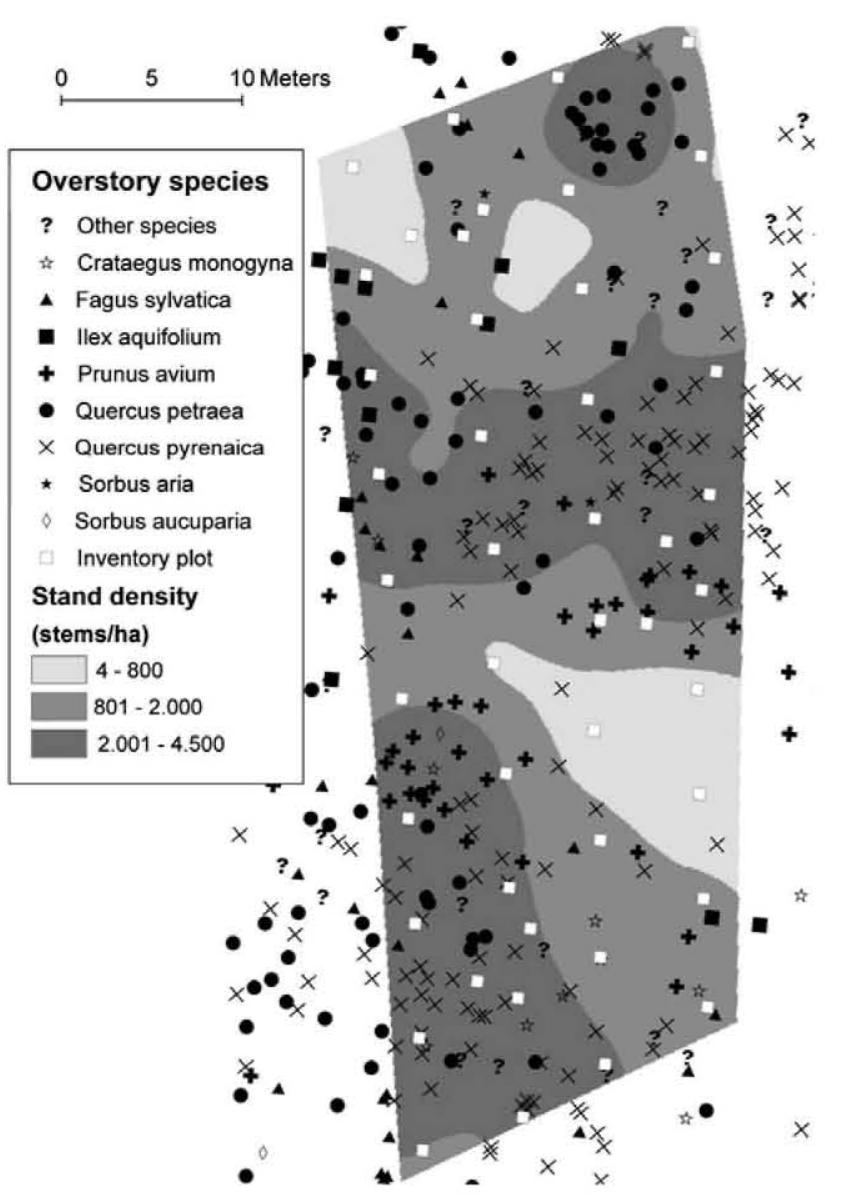

Fig. 1 The experimental plot indicating the sampling plots as well as overstory species location and estimated stand density. Stand density is calculated using a simple kernel-density estimator 
Sampling

In March 2006, 46 floristic plots each of $0.25 \mathrm{~m}^{2}$ were located within the site (see Fig. 1). The same observer counted and measured the cover of all vascular plant species (woody seedlings, herbaceous plants and ferns) within the 46 plots. Regular surveys were carried out from late April to early June, which involved sampling most of species present in the plots according to local checklists of plant species (Hernández-Bermejo et al. 1983). Specimens were initially assigned a code until they flowered or fructified and could be identified. Two taxa from the genus Legousia and Ranunculus could not be specified and were coded as Legousia sp. and Ranunculus sp., respectively. Nomenclature follows Flora Europaea (Tutin et al. 1964).

To estimate understory light availability, we made one hemispherical photograph in each plot at $0.5 \mathrm{~m}$ above the ground. Photos were taken with a digital camera (Nikon Coolpix 4500) coupled with a fish-eye lens and mounted on a self-levelling platform. They were taken at the end of two summer days within the same week, when overstory leaf cover was complete. Images were analyzed with Hemiview 2.1 Canopy Analysis Software (Delta-T, UK). Percent values of full sunlight (global site factor, GSF) were estimated from values of direct and diffuse radiation (Rich et al. 1993). Given the absence of shrubs in the understory, light availability at $0.5 \mathrm{~m}$ height was fully representative of overstory light transmission. Litter amount was estimated by measuring the depth of the litter layer with a ruler (to the nearest $5 \mathrm{~mm}$ ) in two points per plot. Litter was mostly composed of tree leaves.

\section{Data analyses}

\section{Understory species richness}

We computed the number and diameter of all stems ( $>2 \mathrm{~cm}$ DBH) surrounding each floristic plot within a 6-mradius circular area. The total basal area (all tree species together; $\mathrm{BA}_{\mathrm{T}}$ ) and the proportional basal area of the $i$ th tree species $\left(\mathrm{BA}_{i}=\mathrm{BA}_{i} / \mathrm{BA}_{\mathrm{T}}\right)$ were then calculated for each plot. This was made in order to estimate the relative importance of overstory abundance (i.e. density and $\mathrm{BA}_{\mathrm{T}}$ ) and composition (i.e. $\mathrm{BA}_{i}$ ) in controlling soil litter depth, understory light and plant species richness (number of species referred to the floristic plot). We chose 6-m radius for the circular areas to capture adequately overstory properties while avoiding an excessive overlapping between adjacent plots and, consequently, over-smoothing of the estimated variables.

An exploratory analysis of the relationships among environmental variables (litter and light availability), overstory variables (density, $\mathrm{BA}_{\mathrm{T}}$ and $\mathrm{BA}_{i}$ ) and understory species richness was made using Pearson correlations. Variables were transformed as $\log (x)$ or $\log (x+1)$ to reach normality of distributions. Then, we examined the causal relationship among variables with path analysis, which is a useful technique to untangle direct and indirect effects of multiply correlated variables on a dependent variable (Shipley 2000; Arbuckle 2003). First, we designed a simple causal model of the effects of overstory abundance on richness, which included $\mathrm{BA}_{\mathrm{T}}$ as indicative of overstory abundance, and understory light (GSF) and litter depth as environmental endogenous variables. Then, we tested for the influence of overstory composition on richness by gradually incorporating into the model the proportional basal areas of the tree species. Variables were retained into the model if they were significantly linked to other variables. New paths were included if they were significant and resulted in increased goodness of fit of the model. The goodness of fit was evaluated by the $\chi^{2}$ test and the normed fit index (Schermelleh-Engel et al. 2003). The $\chi^{2}$ test has an associated significance test; if the $P$ value associated to $\chi^{2}$ is higher than 0.05 , the structure of the model is acceptable at a $5 \%$ significance level. The NFI is a descriptive index ranging from 0 to 1 , with values higher than 0.90 indicating acceptable fits. The discrepancy function used for model fitting was the maximum likelihood function. We used the softwares Statistica 7.1 (StatSoft) and AMOS 5.0 (Arbuckle 2003) for analyses.

\section{Understory species composition}

We studied the spatial distribution of understory species using variogram analyses of the species presence-absence data. Due to the non-systematic distribution of some floristic plots (Fig. 1), we used cell declustering prior to variogram computation with a 6-m cell size (cell size was chosen approximately equal to the spacing of the pseudoregular grid characterizing the sampling pattern). Cell declustering assigns plot weights by giving more importance to isolated plots (Goovaerts 1997).

The variograms for some species were pure nugget effect variograms showing absence of spatial correlation. However, based on the visual inspection of experimental variograms, we detected some understory species that exhibited spatial correlation. These species were subjected to a multivariate spatial ordination technique known as multivariate factorial kriging (MFK). The theory of MFK underlying the analysis in this study is presented elsewhere (Goovaerts 1992, 1997; Chilés and Delfiner 1999). In this paper, we describe shortly the main steps of this analysis. For a more detailed description of the method applied to vegetation data, see Nanos et al. (2005), Maestre et al. (2005) and Bellier et al. (2007). 
Multivariate factorial kriging starts by computing experimental direct- and cross-variograms of the original variables (in our case, variables correspond to the species presence-absence data). Subsequently, the linear model of coregionalization (LMC) is adjusted to the experimental variograms (we indicate the total number of variables by $p$ ). The LMC is a set of direct- and crossvariogram models in which all its variogram models are linear combinations of the same set of elementary structures. An LMC with $k=1, \ldots, q$ structures may be written as:

$\gamma_{i j}(\mathbf{h})=b_{i j}^{(\mathbf{1})} g^{(\mathbf{1})}+b_{i j}^{(k)} g^{(k)}(\mathbf{h})+\cdots+b_{i j}^{(q)} g^{(q)}(\mathbf{h}) \forall i, j$

where $\gamma_{i j}(\mathbf{h})$ is the variogram model for variables $i$ and $j$ (the direct-variogram is obtained for $i=j$ ), $b_{i j}^{(k)}$ is the partial sill for the $i j$ th variogram for structure $k$, while $g^{(k)}(\mathbf{h})$ represents the type of variogram model (i.e. exponential, spherical, etc.) for structure $k$. The first structure $g^{(1)}$ represents the nugget-effect model. Using the $\mathrm{LMC}$ in Eq. 1, the problem of fitting a total of $p(p-1) / 2$ variogram models to their experimental counterparts is reduced to the problem of deciding the total number $(q)$ of structures to use, as well as the type (i.e. spherical, exponential, etc.) of each structure. LMC fitting implies adjusting the coefficients $b_{i j}^{(k)}$ of Eq. 1 in such a way that variogram models fit their experimental counterparts. After LMC fitting, we extracted the estimated coefficients $b_{i j}^{(k)}$ and arranged them in matrix form (one matrix for each structure $k$ ):

$\mathbf{B}_{k}=\left[\begin{array}{ccc}b_{11}^{(k)} & \ldots & b_{1 p}^{(k)} \\ \hdashline(k) & \ldots & \dot{b}_{p 1}^{(k)} \\ b_{p 1}^{(k)} & \ldots & b_{p p}\end{array}\right]$

$\mathbf{B}_{k}$ is called the coregionalization matrix for structure $k$ and it is the equivalent of a variance-covariance matrix of PCA. A separate PCA conducted for each of the $k$ coregionalization matrices provided sets of transformation coefficients that were, subsequently, used to compute new composite regionalized variables, called regionalized factors (RFs). For each matrix $\mathbf{B}_{k}$, we retained only the first two RFs, which accounted for most of the dispersion in the data (trace of $\mathbf{B}_{k}$ ).

By analogy to principal components, RFs are unobserved spatial variables specific to the $k$ th spatial scale, resulting from a decomposition of the original variables (note that hereafter the term scale or spatial scale will be used instead of the term structure). RFs account for most of the variability of $\mathbf{B}_{k}$ and may have meaningful ecological interpretations. Note, however, that RFs are specific to the $k$ th spatial scale; the variance of spatial scales different from the one considered is filtered out.
For the geostatistical computations, we used the Isatis software (Isatis 2008). The following statistics have also been computed in order to assist the interpretation of RFs:

1. eigenvalues and eigenvectors of the RFs for each coregionalization matrix,

2. correlation coefficients (for coregionalization matrix $\mathbf{B}_{k}$ ) between the extracted RFs and the initial variables (i.e. the species presence-absence). The pair of correlation coefficients between the first two RFs and the initial variables was presented in a so-called circle of correlation (Saporta 1990). Note that these correlation coefficients are computed based on the LMC parameters $b_{i j}^{(k)}$,

3. product-moment correlation coefficients between the RFs (estimated at the plot level using a modified cokriging system;see Goovaerts 1997) and environmental and stand-structural variables measured also at the plot level (i.e., GSF, soil litter depth, etc.).

\section{Results}

\section{Overstory species composition}

Stem density and basal area were 1,664 stems ha ${ }^{-1}$ and $34.8 \mathrm{~m}^{2} \mathrm{ha}^{-1}$, respectively. $Q$. pyrenaica and $Q$. petraea dominated the plot with 20.4 and $11 \mathrm{~m}^{2} \mathrm{ha}^{-1}$ basal area, respectively. There were few large old Quercus trees remaining from the old wood pasture ( $2 \%$ of trees, $>60 \mathrm{~cm}$ $\mathrm{DBH})$ but most were adults that recruited after grazing ceased in the $1960 \mathrm{~s}$ ( $86 \%$ of trees, ranging from 5 to $25 \mathrm{~cm}$ DBH). Q. pyrenaica and $Q$. petraea were not intermingled but tended to occupy different zones in the plot (Fig. 1). The rest of the overstory species (Fagus sylvatica, Prunus avium and Ilex aquifolium) were less important in terms of basal area (less than $1.5 \mathrm{~m}^{2} \mathrm{ha}^{-1}$ for each one). The presence of $F$. sylvatica was not related to the presence of any other tree, while $P$. avium and $I$. aquifolium were positively associated with $Q$. pyrenaica and $Q$. petraea, respectively (Fig. 1). Occasionally, we recorded the isolated appearance of trees of two Sorbus species (see also Fig. 1).

\section{Understory species richness}

We recorded 49 species in the understory (Table 1 ). The number of species per sampling plot ranged from none to thirteen and total cover ranged from 0 to $64 \%$ (18.9\% on average); both variables showed a strong positive linear relationship ( $r=0.85 ; P<0.001$; not shown).

Total basal area of overstory species around floristic plots $\left(\mathrm{BA}_{\mathrm{T}}\right.$, ranging from 4.7 to $111 \mathrm{~m}^{2} \mathrm{ha}^{-1}$ ) was not 
Table 1 List of plant species found in the understory

\begin{tabular}{|c|c|c|c|c|c|}
\hline Species $^{\mathrm{a}}$ & Abbreviations & Family & $\mathrm{LF}^{\mathrm{b}}$ & $\begin{array}{l}\text { Frequency } \\
(\%)^{\mathrm{c}}\end{array}$ & Habitat preference in the Iberian Peninsula \\
\hline Melica uniflora & $\mathrm{Mu}$ & Gramineae & $\mathrm{H}$ & 59 & Nutrient-rich deciduous forests \\
\hline Prunus avium & $\mathrm{Pa}$ & Rosaceae & $\mathrm{P}$ & 39 & Nutrient-rich deciduous forests \\
\hline Alliaria petiolata & Ap & Cruciferae & $\mathrm{H}$ & 39 & $\begin{array}{l}\text { Nutrient-rich sites; shady forest edges. Mainly } \\
\text { ruderal }\end{array}$ \\
\hline Galium aparine & $\mathrm{Ga}$ & Rubiaceae & $\mathrm{T}$ & 35 & Nutrient-rich sites; shady forest edges \\
\hline Lapsana communis & Lc & Compositae & $\mathrm{T}$ & 24 & $\begin{array}{l}\text { Nutrient-rich sites; shady forest edges. Mainly } \\
\text { ruderal }\end{array}$ \\
\hline Cruciata glabra & $\mathrm{Cg}$ & Rubiaceae & $\mathrm{H}$ & 22 & Nutrient-rich sites; shady forest edges \\
\hline Stellaria media & $\mathrm{Sm}$ & Caryophyllaceae & $\mathrm{T}$ & 22 & Nutrient-rich sites. Mainly ruderal \\
\hline Conopodium bourgaei & $\mathrm{Cb}$ & Umbelliferae & $\mathrm{H}$ & 20 & Deciduous forests \\
\hline Arenaria montana & Am & Caryophyllaceae & $\mathrm{H}$ & 17 & Deciduous forests, mainly on acidic soils \\
\hline Hedera helix & $\mathrm{Hh}$ & Araliaceae & $\mathrm{P}$ & 17 & Deciduous forests \\
\hline Ranunculus sp. & $\mathrm{R}$ & Ranunculaceae & & 17 & \\
\hline Veronica hederifolia & $\mathrm{Vh}$ & Scrophulariaceae & $\mathrm{T}$ & 17 & $\begin{array}{l}\text { Nutrient-rich and wet sites; shady forest edges. } \\
\text { Mainly ruderal }\end{array}$ \\
\hline Holcus mollis & $\mathrm{Hm}$ & Gramineae & $\mathrm{H}$ & 15 & $\begin{array}{l}\text { Deciduous and marcescent forests, mainly on acidic } \\
\text { soils }\end{array}$ \\
\hline Myrrhoides nodosa & Mn & Umbelliferae & $\mathrm{T}$ & 15 & $\begin{array}{l}\text { Sub-Mediterranean nutrient-rich sites and shady } \\
\text { forest edges. Mainly ruderal }\end{array}$ \\
\hline Quercus pyrenaica & Qpy & Fagaceae & $\mathrm{P}$ & 15 & $\begin{array}{l}\text { Sites with acidic soils and sub-Mediterranean } \\
\text { climate }\end{array}$ \\
\hline Festuca heterophylla & Fh & Gramineae & $\mathrm{H}$ & 13 & Deciduous and marcescent forests \\
\hline Hyacinthoides hispanica & Hhy & Liliaceae & $\mathrm{G}$ & 11 & Mediterranean forests on acidic soils \\
\hline Quercus petraea & Qpe & Fagaceae & $\mathrm{P}$ & 11 & Sites with temperate climate \\
\hline
\end{tabular}

${ }^{a}$ Species present in less than $10 \%$ of plots were: Achillea millefolium, Agrostis capillaris, Agrostis castellana, Allium oleraceum, Hepatica nobilis, Avenula marginata, Cardamine hirsuta, Centaurea triumfetti, Clinopodium vulgare, Dactylis glomerata, Deschampsia flexuosa, Erica arborea, Gagea nevadensis, Genista florida, Geranium robertianum, Geum urbanum, Holcus lanatus, Ilex aquifolium, Lathyrus pratensis, Legousia sp., Lonicera periclymenum, Luzula lactea, Omithogalum umbellatum, Poa nemoralis, Pteridium aquilinum, Ranunculus ficaria, Ranunculus gregarius, Rosa canina, Silene nutans, Taraxacum officinale, Veronica chamaedrys

${ }^{\mathrm{b}}$ Life form according to Räunkiaer's classification: $T$ Therophyte; $H$ Hemicryptophyte; $G$ Geophyte; $P$ Phanerophyte

${ }^{c}$ Frequency of presence (percent of plots)

related with understory richness nor with any other variable related with richness (Table 2 ), and similar results were found for stem density (not shown). On the contrary, the proportional basal area of each tree species was associated with understory richness. The increasing proportion of Q. petraea in the overstory $\left(\mathrm{BA}_{\mathrm{Qpe}}\right)$ was associated with lower richness in the understory, while the opposite was true for Q. pyrenaica (BA $\mathrm{B}_{\mathrm{Qpy}}$ ) and P. avium (BA $\mathrm{BAv}_{\mathrm{Pav}}$ ). Litter depth (ranging from 1 to $11 \mathrm{~cm}$ ) exhibited a strong negative correlation with species richness (Table 2). In turn, litter depth positively correlated with $\mathrm{BA}_{\mathrm{Qpe}}$ and $\mathrm{BA}_{\mathrm{Fsy}}$, and negatively with $\mathrm{BA}_{\mathrm{Pav}}$.

Path analyses confirmed that $\mathrm{BA}_{\mathrm{T}}$ had no effect on richness (Fig. 2a). In contrast, including the proportional basal area of certain tree species increased the overall goodness of fit of the model and the proportion of variation in richness explained by the model (Fig. 2b). The proportional basal area of $F$. sylvatica had an indirect negative effect on richness, since litter accumulated to a higher extent as $\mathrm{BA}_{\mathrm{Fsy}}$ increased and, in turn, litter caused a decline on richness. In contrast, we observed an indirect positive effect of $P$. avium (BA $\mathrm{B}_{\mathrm{Pav}}$ ) on richness via decreased litter accumulation. Marginally significant direct effects of $\mathrm{BA}_{\mathrm{Pav}}$ and $\mathrm{BA}_{\mathrm{Qpe}}$ on richness were also observed. Light availability (ranging from 7.9 to $27.5 \%$ full sunlight) showed no effect on richness. Path analyses were also conducted using absolute basal area to substitute the relative basal area for each species in the 6-m circular plots and results were essentially the same to the ones already presented (not shown).

\section{Understory species composition}

Of the 49 species found in the understory, nine were young plants of woody species: trees ( $Q$. petraea, $P$. avium, Q. pyrenaica and I. aquifolium), shrubs (Rosa canina, 
Table 2 Pearson correlation coefficients

\begin{tabular}{|c|c|c|c|c|c|c|c|c|c|}
\hline & $\mathrm{BA}_{\mathrm{T}}$ & BA $_{\text {Iaq }}$ & $\mathrm{BA}_{\mathrm{Pav}}$ & $\mathrm{BA}_{\mathrm{Fsy}}$ & $\mathrm{BA}_{\mathrm{Qpy}}$ & BA $_{\text {Qpe }}$ & GSF & Litter & Richness \\
\hline $\mathbf{B A}_{\mathrm{T}}$ & 1.00 & & & & & & & & \\
\hline BA $_{\text {Iaq }}$ & 0.01 & 1.00 & & & & & & & \\
\hline $\mathbf{B} A_{\text {Pav }}$ & -0.18 & -0.32 & 1.00 & & & & & & \\
\hline $\mathrm{BA}_{\mathrm{Fsy}}$ & -0.20 & 0.12 & -0.04 & 1.00 & & & & & \\
\hline $\mathrm{BA}_{\mathrm{Qpy}}$ & -0.27 & -0.44 & 0.36 & -0.06 & 1.00 & & & & \\
\hline $\mathrm{BA}_{\mathrm{Qpe}}$ & -0.09 & 0.35 & -0.47 & 0.25 & -0.67 & 1.00 & & & \\
\hline GSF & -0.16 & 0.03 & 0.43 & -0.16 & -0.07 & -0.02 & 1.00 & & \\
\hline Litter & 0.07 & 0.26 & -0.37 & 0.42 & -0.17 & 0.36 & -0.28 & 1.00 & \\
\hline Richness & -0.15 & -0.13 & 0.51 & -0.15 & 0.30 & -0.53 & 0.28 & -0.72 & 1.00 \\
\hline
\end{tabular}

Variables are total basal area $\left(\mathrm{BA}_{\mathrm{T}}\right)$; proportional basal areas of $I$. aquifolium $\left(\mathrm{BA}_{\mathrm{Iaq}}\right), P$. avium $\left(\mathrm{BA}_{\mathrm{Pav}}\right), F$. sylvatica $\left(\mathrm{BA}_{\mathrm{Fsy}}\right), Q$. pyrenaica $\left(\mathrm{BA}_{\mathrm{Qpy}}\right)$ and $Q$. petraea $\left(\mathrm{BA}_{\mathrm{Qpe}}\right)$; light availability (GSF); litter; and plant species richness

Values in bold are significant at $P<0.05$

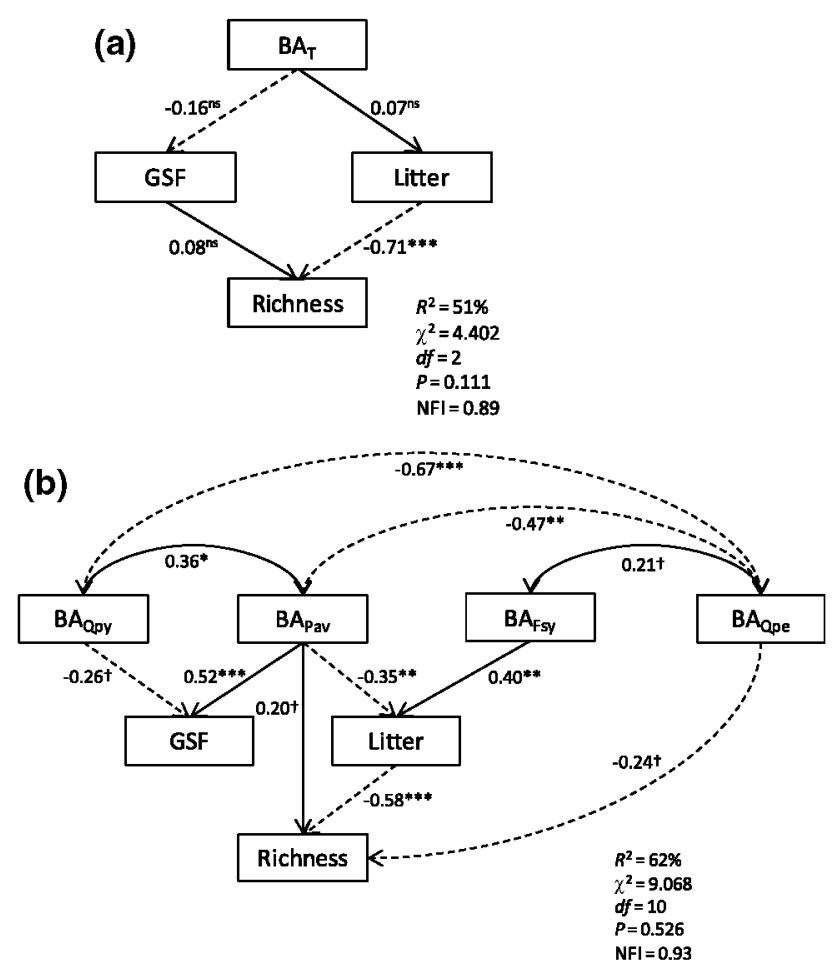

Fig. 2 Path models of the effects of total basal area of overstory species $\left(\mathrm{BA}_{\mathrm{T}}\right)$ (a) and of proportional basal areas of tree species (b) on understory species richness. Path coefficients and associated $P$ values $\left({ }^{* * *} P<0.001 ;{ }^{* *} P<0.01 ;{ }^{\dagger} P<0.10 ;{ }^{\text {ns }} P \geq 0.10\right)$ are shown besides each path. The proportion of variation in richness explained by the models $\left(R^{2}\right)$ and two indexes of overall goodness of fit are shown $\left[\chi^{2}\right.$ with associated degrees of freedom $(d f)$ and $P$-value, and NFI]. Dashed and continuous lines represent negative and positive associations between variables, respectively

Genista florida and Erica arborea) and climbers (Hedera helix and Lonicera periclymenum). The most common life form category among herbaceous species was hemicryptophyte $(50 \%)$. Twenty-six percent of herbaceous species were grasses. We noted the presence of some grasses typical of temperate forests rare in Mediterranean areas, such as Melica uniflora (present in 59\% of plots) and Poa nemoralis $(9 \%)$. We also noted the profusion of nitrophilous herbs, such as Alliaria petiolata (39\%), Galium aparine (35\%), Stellaria media (22\%), Lapsana communis (22\%), Veronica hederifolia (17\%) and Myrrhoides nodosa $(15 \%)$ (Table 1); they probably reveal the prior use of the forest as a wood pasture.

Spatial correlation was absent for 40 species. Thirty-one species appeared in less than 5 plots, while 9 species (Festuca heterophylla, Ranunculus sp., Alliaria petiolata, Myrrhoides nodosa, Lapsana communis, Q. pyrenaica, Q. petraea, Hyacinthoides hispanica and Hedera helix) did not show any spatial correlation that could be detectable at our scale of observation in spite of being very abundant. Finally, 9 abundant species exhibited spatial correlation with a range of approximately $10-15 \mathrm{~m}$ : Arenaria montana (Am), Conopodium bourgaei $(\mathrm{Cb})$, Cruciata glabra $(\mathrm{Cg})$, Galium aparine $(\mathrm{Ga})$, Holcus mollis $(\mathrm{Hm})$, Melica unifora $(\mathrm{Mu})$, P. avium $(\mathrm{Pa})$, Stellaria media $(\mathrm{Sm})$ and Veronica hederifolia (Vh).

The LMC for the 9 species that presented spatial correlation has three elementary structures, namely a nugget effect and two spherical variogram models with 6- and 14-m ranges of spatial correlation (Fig. 3). The 6-m structure was included to model the experimental variograms of two species (Vh and $\mathrm{Sm}$ ) that seemed to exhibit spatial correlation at distances of approximately $6 \mathrm{~m}$. The majority of understory species, however, presented variograms with 14-m range of spatial correlation (see, for instance, $\mathrm{Cb}$ or Am in Fig. 3).

The correlation circle for the $14-\mathrm{m}$ scale of variation is presented in Fig. 4. The circle is dominated by the isolated occurrence of $\mathrm{Mu}$ that seems to exhibit a negative correlation with all the other understory species at this spatial 

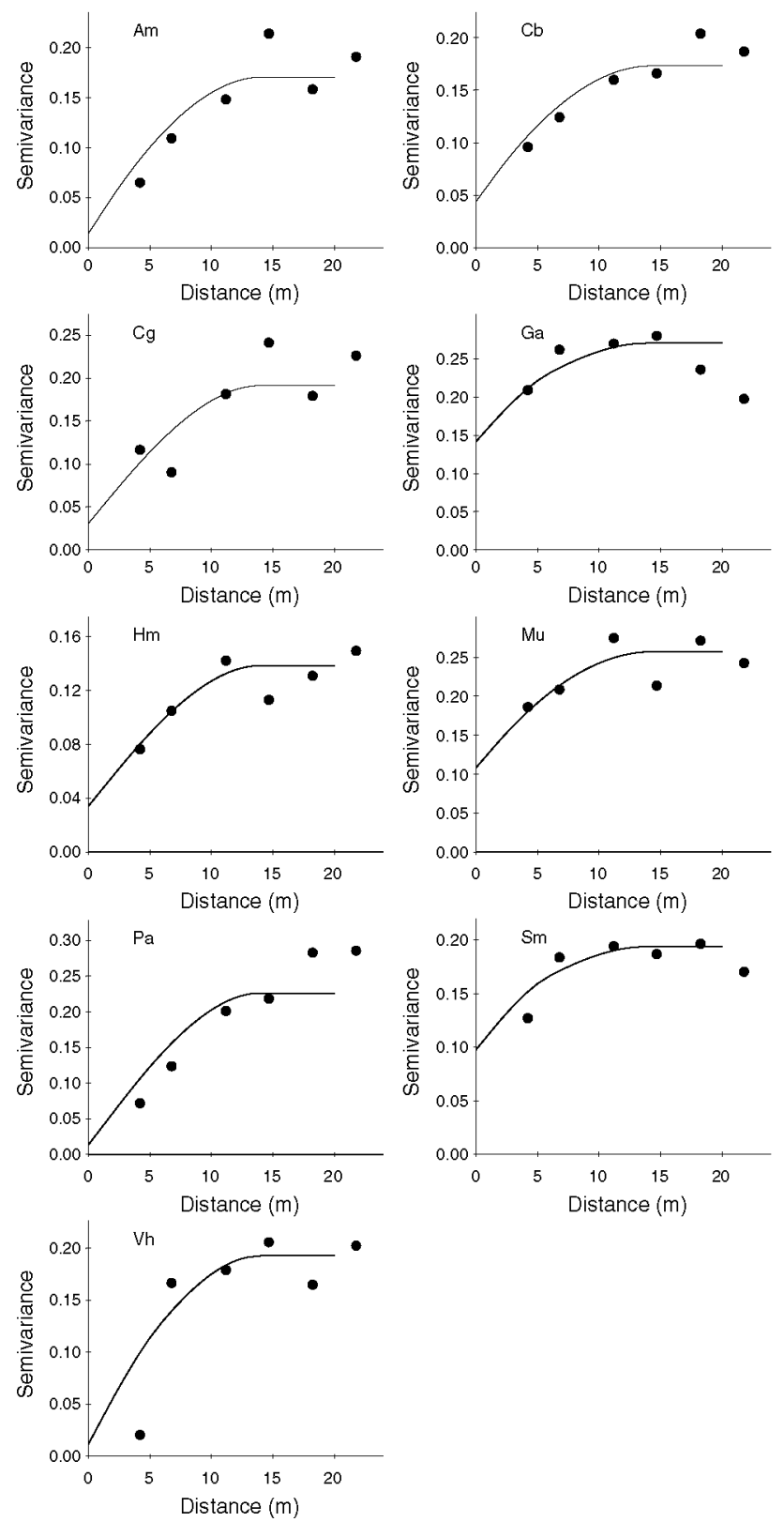

Fig. 3 Linear model of coregionalization (LMC) for 9 understory species that presented spatial correlation (cross-variograms are omitted). Black dots are the semivariance values of the corresponding experimental variogram and the continuous lines represent the adjusted LMC

scale (something that can also be appreciated in the cokriging maps for the probability of species presence; see Fig. 5). The isolation of $\mathrm{Mu}$ is especially prominent in the first RF where the species takes a high negative loading, contrary to a plethora of species found on the positive extreme of the RF ( $\mathrm{Cg}, \mathrm{Am}, \mathrm{PA}, \mathrm{Cb}, \mathrm{Ga}, \mathrm{Hm})$. The first $\mathrm{RF}$ correlates positively with the presence of $Q$. pyrenaica overstory trees $(0.49)$ but negatively with the presence of Q.petraea $(-0.53)$ and soil litter depth $(-0.40)$ (Table 3$)$.
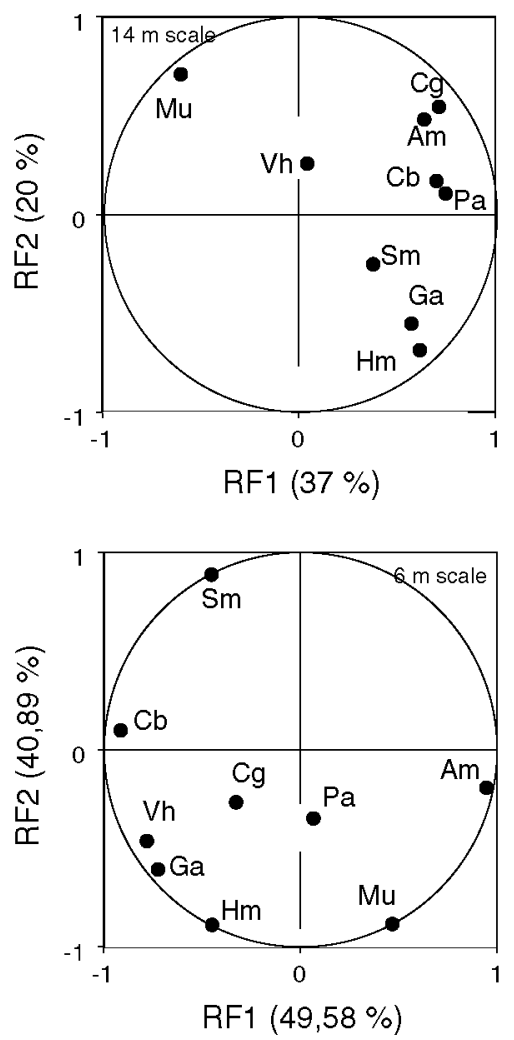

Fig. 4 Correlation circle for the first two regionalized factors of the 14- and 6-m scales of variation

The second RF, which accounts for $20 \%$ of the variance for this spatial scale, takes on high positive values for plots with presence of $\mathrm{Mu}, \mathrm{Cg}$ and $\mathrm{Am}$ and negative values for plots with presence of $\mathrm{Hm}$ and $\mathrm{Ga}$. Other species such as $\mathrm{Pa}, \mathrm{Cb}$ or $\mathrm{Sm}$ have lower loadings for this $\mathrm{RF}$. The second $\mathrm{RF}$ is well correlated with light availability $(0.44$; see Table 3) but, contrary to the first RF, it is not well correlated with the basal area of overstory species. Note, finally, that similar to the first RF, soil litter accumulation presents a negative sign in its correlation coefficient with the second RF (Table 3).

Species associations at the 6-m scale of variation are substantially different from the ones presented in the 14-m scale (Fig. 4). Interestingly, the seven-species association reported in the previous spatial scale is absent from this scale whereas Stellaria media $(\mathrm{Sm})$ is now found to be the most isolated species. On the other hand, it can be observed that understory species are less associated between each other and that, contrary to the previous scale of variation, no clear species groupings can be identified. Finally, correlations between the two RFs and measured environmental and stand variables are substantially smaller at this scale (Table 3), with the highest correlation coefficient $(0.28)$ recorded between RF1 and the basal area of $P$. avium. 


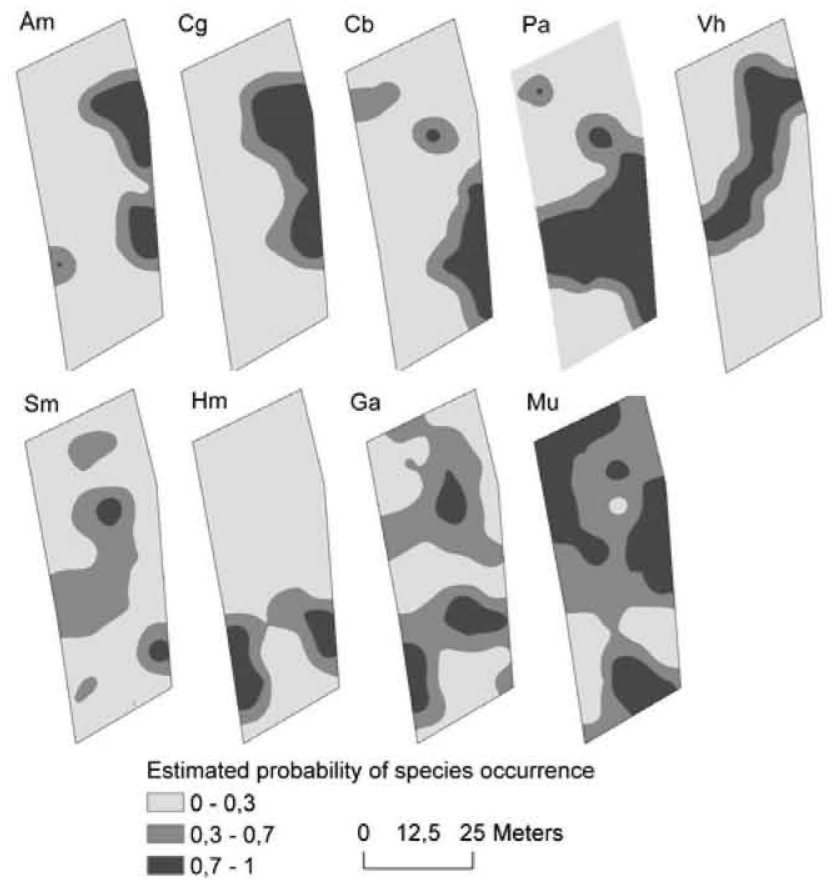

Fig. 5 Cokriging estimates of understory species (species abbreviations are shown in Table 1). Maps for understory species were produced using the lineal coregionalization model (see also Fig. 3). These maps represent the probability that a species is present in the understory (dark colors indicate higher probability of occurrence). Note the (estimated) mutual habitat for some understory species such as the Arenaria montana-Cruciata glabra association at the right side of the study plot

\section{Discussion}

\section{Understory species richness}

In a relatively closed mixed hardwood stand, the variation of plant species richness in the understory was related to the extent of litter accumulation on the floor, which, in turn, was associated with the overstory composition. Our results suggest that the presence of some tree species in the overstory, even if occasional, contributes to create patches of variable diversity in the understory due, in part, to the variable accumulation of their litter on the forest floor.

The occasional presence of $F$. sylvatica in the overstory brought about a decline in understory species richness. In mixed Picea abies- and Pinus sylvestris-F. sylvatica stands, increased prevalence of $F$. sylvatica has been shown to reduce the species richness of different plant functional groups (Simmons and Buckley 1992; Ewald 2000; Barbier et al. 2008). Of the number of mechanisms that may arrest seed-to-seedling performance beneath the canopy of $F$. sylvatica, our results indicated that litter accumulation played an important role, as suggested by Pardo et al. (1997).
Table 3 Correlation coefficients between regionalized factors (14- and 6-m scales of variation) and environmental and stand-structural variables

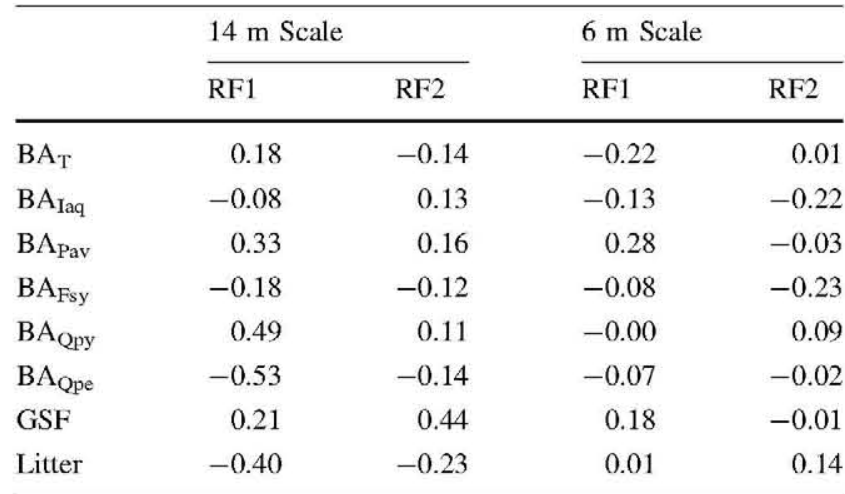

Basal areas were computed based on trees located within circles of 6-m radius around the plot

Environmental variables are litter and light availability (GSF); standstructural variables are basal area of all species $\left(\mathrm{BA}_{\mathrm{T}}\right)$, basal area of Q. pyrenaica $\left(\mathrm{BA}_{\mathrm{Qpy}}\right)$, Q. petraea $\left(\mathrm{BA}_{\mathrm{Qpe}}\right)$, P. avium $\left(\mathrm{BA}_{\mathrm{Pav}}\right)$, F. sylvatica $\left(\mathrm{BA}_{\mathrm{Fsy}}\right)$ and I. aquifolium $\left(\mathrm{BA}_{\mathrm{Iaq}}\right)$

$R F$ Regionalized factor score

Positive effects of litter on seeds and plants disappear when accumulation of litter exceeds certain limits (Sydes and Grime 1981). The main negative effect is the obstruction for rooting and/or emergence of seedlings, but several others have been suggested (Facelli and Pickett 1991). Moreover, the alteration of different physicochemical soil properties caused by litter accumulation can also affect the germination of seeds and the performance of plants (e.g., Dzwonko and Garownski 2002).

Assuming that leaves from neighboring trees mainly composed the soil litter, higher litter depth around trees of $F$. sylvatica could reflect a slower decomposition of its leaves. Leaf litter composition affects the rate of litter disappearance depending on the functional traits of component species (Pérez-Harguindeguy et al. 2000; Hobbie et al. 2006; Kazakou et al. 2006; Aubert et al. 2010). For example, Hobbie et al. (2006) observed in a common garden experiment with 14 tree species that the slowest rate of leaf litter decomposition among hardwoods corresponded to F. sylvatica. Likewise, Aubert et al. (2010) reported a slower rate of litter disappearance in litterbags when they were filled with $F$. sylvatica than when they were filled with Carpinus betulus. In our study forest, Pardo (2000) observed that the percentage of litter mass remaining in bags placed for 2 years beneath conspecific stands ranked: $F$. sylvatica $>Q$. petraea $>Q$. pyrenaica, matching their ranking of shade tolerance. The relatively high lignin-to-nitrogen ratio of $F$. sylvatica leaves is one of the factors that underpin their inherently low decomposability (Sariyildiz and Anderson 2005). 
On the other hand, the presence of $P$. avium in the overstory was positively related with understory richness. Individuals of this relatively shade-intolerant tree species occupied the least dense, most open areas of the plot where understory light availability was higher. Such conditions are generally favorable for species, but still we saw that the main effect on richness was mediated by a decline on litter depth. In turn, the decrease in litter depth as the relative abundance of $P$. avium increased was not related to canopy closure, which suggests a faster decomposability of $P$. avium litter relative to the other trees (Aubert et al. 2010).

\section{Understory species composition}

The most outstanding species association at the largest spatial scale studied $(14 \mathrm{~m})$ was the one formed by Cruciata glabra, Arenaria montana, Prunus avium, Conopodium bourgaei, Holcus mollis, Stellaria media and Galium aparine. These species were located on the right part of the correlation circle, in contrast to Melica uniflora, which was located on the left part of the same circle (Fig. 4). Based on the correlation coefficients between the RF1 and the stand-structural variables (Table 3), we suggest that the increasing proportion of $Q$. pyrenaica and $P$. avium in the overstory favored the presence of Cruciata glabra, Arenaria montana, Prunus avium, Conopodium bourgaei, Holcus mollis, Stellaria media and Galium aparine in the understory. Conversely, the increasing proportion of $Q$. petraea and to a lower extent $F$. sylvatica favored the presence of Melica uniflora. The RF1 also corresponded to a gradient of litter accumulation. Thus, litter accumulation in the understory appeared to constrain the expansion of the cluster of seven species but to favor that of Melica uniflora, which is consistent with a variable response of plant species to litter depth (Sydes and Grime 1981). It is interesting that Melica uniflora-previously described as sensitive to disturbance (Borchsenius et al. 2004) was preferentially present where litter was more abundant. In addition, it is remarkable that Melica uniflora tended to appear beneath the canopy of $Q$. petraea and $F$. sylvatica-two trees that are at the edge of their distribution in Europe in the study forest-suggesting an association between overstory and herbaceous species under marginal conditions. One might think that the contrasting spatial pattern of Melica uniflora with respect to the other species (Fig. 3) is attributable to distancedependent competitive interactions among understory species. However, if we accept that interspecific competition acts only at the floristic plot-level scale of variation (Nanos et al. 2005), and given that our results are specific to the 14-m scale, it seems plausible to exclude competition as a factor responsible for the isolation of Melica uniflora from the rest of species.

Within the studied stand, understory species appeared less associated when the 6-m scale of variation was considered. Additionally, it seems that the correlations between RFs (that represent scale-specific species associations) and environmental and/or stand variables are reduced when moving to the small spatial scale. Based on these findings, we suggest that understory species associations and the corresponding overstory effects on species assemblages are becoming less obvious when observing at gradually smaller spatial scales. Such scale-dependent correlations should appear naturally as the result of random seed dispersal processes as well as due to small-scale microenvironmental factors (such as rock presence or sunflecks) that obscure the large-scale effect of overstory composition and abundance on the understory vegetation pattern. A more rigorous examination of scale-dependent correlations should make use of scale-dependent canonical correlation techniques (Wackernagel 1995). Nevertheless, both the environmental and the stand-structural variables used in this study did not present scale-dependent variation (direct variograms not shown) and, therefore, correlations between scale-dependent species assemblages and plotlevel environmental and stand-structural variables are equally trustfulworthy.

Overstory characteristics, on the other hand, did not have any detectable influence on the spatial distribution of nine randomly distributed and abundant understory species (Festuca heterophylla, Ranunculus sp., Alliaria petiolata, Myrrhoides nodosa, Lapsana communis, Q. pyrenaica, Q. petraea, Hyacinthoides hispanica and Hedera helix). The absence of clustering at the 14-m spatial scale reflects a suitable range of conditions for performance of all species, which establish, compete for resources, and disperse across the full range of microhabitats (Werger and Van der Maarel 1978). This is not at the expense of the notion of lottery recruitment, under which a different set of species of similar ecological limits could have manifested a random distribution pattern at a different time (e.g., Lavorel and Lebreton 1992).

The majority of understory species (not included in the spatial analysis) appeared in too few plots to be able to model their spatial distribution. Some species might simply have an occasional presence in the understory, such as Clinopodium vulgare and Lathyrus pratensis, which are more typical of open grasslands. The paucity of other species, such as forest herbs Hyacinthoides hispanica and Hepatica nobilis, might reflect their limited ecological amplitude, i.e. only certain microsites satisfied their vegetative and reproductive demands. This contributes to the difficulty for modeling the distribution of rare species, which often have a high conservation value. 
Concluding remarks

Small-scale variations in overstory composition in a mixed forest stand contributed to shape the composition and richness of understory vegetation. Tree species affected litter depth. The presence of $F$. sylvatica, for instance, created patches of reduced richness due to an accumulation of litter. Only the occurrence of Melica uniflora, a forest grass species rare in the Mediterranean, seemed to be favored by litter accumulation and was mostly found under the canopy of $F$. sylvatica and particularly $Q$. petraea. This situation reflects the decreasing diversity and changing composition of plant species in the understory as forest succession advances and shade-tolerant trees reach the canopy.

Acknowledgments We thank Jesús Alonso for assisting in tree mapping, and Dr. Alfonso San Miguel for his help in plant identification. We also acknowledge two anonymous reviewers and the corresponding editor for helpful advice on data analyses. Financial support for this study was provided by projects CCG06-UPM/AMB360 and AGL2006-00813.

\section{References}

Arbuckle JL (2003) AMOS 5 user's guide. Smallwaters, Chicago

Aubert M, Margerie P, Trap J, Bureau F (2010) Abovegroundbelowground relationships in temperate forests: plant litter composes and microbiota orchestrates. For Ecol Manage 259:563-572

Barbier S, Gosselin F, Balandier P (2008) Influence of tree species on understory vegetation diversity and mechanisms involved-a critical review for temperate and boreal forests. For Ecol Manage 254:1-15

Bazzaz FA (1996) Plants in changing environments-linking physiological, population, and community ecology. Cambridge University Press, Cambridge

Beatty SW (1984) Influence of microtopography and canopy species on spatial patterns of forest understory plants. Ecology 65:1406-1419

Bellier E, Monestiez P, Durbec JP, Candau JN (2007) Identifying spatial relationships at multiple scales: principal coordinates of neighbour matrices (PCNM) and geostatistical approaches. Ecography 30:385-399

Berger AL, Puettmann KJ (2000) Overstory composition and stand structure influence herbaceous plant diversity in the mixed aspen forest of northern Minnesota. Am Midl Nat 143:111-125

Borchsenius F, Nielsen PK, Lawesson JE (2004) Vegetation structure and diversity of an ancient temperate deciduous forest in SW Denmark. Plant Ecol 175:121-135

Canham CD, Finzi AC, Pacala SW, Burbank DH (1994) Causes and consequences of resource heterogeneity in forests: interspecific variation in light transmission by canopy trees. Can $\mathbf{J}$ For Res 24:337-349

Casado MA, Castro I, Ramírez-Sanz L, Costa-Tenorio M, de Miguel JM, Pineda FD (2004) Herbaceous plant richness and vegetation cover in Mediterranean grasslands and shrublands. Plant Ecol 170:83-91

Chilés JP, Delfiner P (1999) Geostatistics: modeling spatial uncertainty. Wiley, New York
Crozier CR, Boerner REJ (1984) Correlations of understory herb distribution patterns with microhabitats under different tree species in a mixed mesophytic forest. Oecologia 62:337-343

Dzwonko Z, Garownski S (2002) Effect of litter removal on species richness and acidification of a mixed oak-pine woodland. Biol Conserv 106:389-398

Ewald J (2000) The influence of coniferous canopies on understory vegetation and soils in mountain forests of the northern Calcareous Alps. Appl Veg Sci 3:123-134

Facelli JM, Pickett STA (1991) Plant litter: its dynamics and effects on plant community structure. Bot Rev 57:1-32

Goovaerts P (1992) Factorial kriging analysis: a useful tool for exploring the structure of multivariate spatial information. J Soil Sci 43:597-619

Goovaerts P (1997) Geostatistics for natural resources evaluation. Oxford University Press, New York

Hernández-Bermejo JE, Costa Tenorio M, Sáinz Ollero H, Clemente Muñoz M (1983) Catalogo florístico del Hayedo de Montejo de la Sierra (provincia de Madrid). Lagascalia 11:3-65

Hobbie SE, Reich PB, Oleksyn J, Ogdahl M, Zytkowiak R, Hale C, Karolewski $P$ (2006) Tree species effects on decomposition and forest floor dynamics in a common garden. Ecology 87:2288-2297

Howard LF, Lee TD (2003) Temporal patterns of vascular plant diversity in southeastern New Hampshire forests. For Ecol Manage 185:5-20

Isatis (2008) Isatis software manual. Geovariances and Ecole des Mines de Paris

Jobidon R, Cyr G, Thiffault N (2004) Plant species diversity and composition along an experimental gradient of northern hardwood abundance in Picea mariana plantations. For Ecol Manage 198:209-221

Kato S, Komiyama A (2002) Spatial and seasonal heterogeneity in understory light conditions caused by differential leaf flushing of deciduous overstory trees. Ecol Res 17:687-693

Kazakou E, Vile D, Shipley B, Gallet C, Garnier E (2006) Covariations in litter decomposition, leaf traits and plant growth in species from a Mediterranean old-field succession. Funct Ecol 20:21-30

Komiyama A, Kato S, Teranishi M (2001) Differential overstory leaf flushing contributes to the formation of a patchy understory. J For Res 6:163-171

Lavorel S, Lebreton JD (1992) Evidence for lottery recruitment in Mediterranean old fields. J Veg Sci 3:91-98

Maestre FT, Rodríguez F, Bautista S, Cortina J, Bellot J (2005) Spatial associations and patterns of perennial vegetation in a semi-arid steppe: a multivariate geostatistics approach. Plant Ecol 179:133-147

Maltez-Mouro S, García LV, Marañón T, Freitas H (2005) The combined role of topography and overstorey tree composition in promoting edaphic and floristic variation in a Mediterranean forest. Ecol Res 20:668-677

Nanos N, Pardo F, Alonso J, Pardos JA, Gil L (2005) Using multivariate factorial kriging for multiscale ordination: a case study. Can J For Res 35:2860-2874

Pardo F (2000) Caracterización de rodales arbolados del Hayedo de Montejo (Madrid): estructura, composición e incorporación de la hojarasca al suelo. $\mathrm{PhD}$ thesis

Pardo F, Gil L, Pardos JA (1997) Field study of beech (Fagus sylvatica L.) and melojo oak (Quercus pyrenaica Willd) leaf litter decomposition in the centre of the Iberian Peninsula. Plant Soil 77:67-74

Pérez-Harguindeguy N, Díaz S, Cornelissen JHC, Vendramini F, Cabido M, Castellanos A (2000) Chemistry and toughness predict leaf litter decomposition rates over a wide spectrum of functional types and taxa in central Argentina. Plant Soil 218:21-30 
Rich PM, Clark DB, Clark DA, Oberbauer SF (1993) Long-term study of solar radiation regimes in a tropical wet forest using quantum sensors and hemispherical photography. Agric For Meteorol 65:107-127

Saporta A (1990) Probabilités, analyse des données et statistique. Technip, Paris

Sariyildiz T, Anderson JM (2005) Variation in the chemical composition of green leaves and leaf litters from three deciduous tree species growing on different soil types. For Ecol Manage 210:303-319

Schermelleh-Engel K, Moosbrugger H, Müller H (2003) Evaluating the fit of structural equation models: tests of significance and descriptive goodness-of-fit measures. Methods Psychol Res Online 8:23-74

Schumann ME, White AS, Witham JW (2003) The effects of harvestcreated gaps on plant species diversity, composition, and abundance in a Maine oak-pine forest. For Ecol Manage $176: 543-561$

Shipley B (2000) Cause and correlation in biology - a user's guide to path analysis, structural equations and causal inference. Cambridge University Press, Cambridge
Simmons EA, Buckley GP (1992) Ground vegetation under planted mixtures of trees. In: Cannell MGR, Malcolm DC, Robertson PA (eds) The ecology of mixed-species stands of trees. Blackwell, Oxford, pp 211-231

Sydes C, Grime JP (1981) Effects of tree leaf litter on herbaceous vegetation in deciduous woodland: I. Field investigations. J Ecol 69:237-248

Thomsen RP, Svenning JC, Balslev H (2005) Overstorey control of understorey species composition in a near-natural temperate broadleaved forest in Denmark. Plant Ecol 181:113-126

Tutin TG, Heywood VH, Burges NA, Moore DM, Valentine DH, Walters SM, Webb DA (1964-1980) Flora Europaea. Cambridge University Press, Cambridge

Wackernagel H (1995) Multivariate geostatistics. An introduction with applications. Springer, Berlin, $235 \mathrm{p}$

Werger MJA, van der Maarel E (1978) Plant species and plant communities: some conclusions. In: van der Maarel E, Werger MJA (eds) Plant species and plant communities. Junk, The Hague, pp 169-175 